\title{
PENGATURAN LAMPU LALULINTAS BERBASIS FUZZY LOGIC
}

\author{
SETIANTO $^{* 1}$, LIU KIN MEN ${ }^{1}$, BAMBANG MUKTI WIBAWA ${ }^{2}$, DARMAWAN HIDAYAT $^{2}$ \\ ${ }^{1}$ Departemen Fisika Fakultas MIPA Universitas Padjadjaran, \\ Jl. Raya Bandung-Sumedang Km 21, Jatinangor 45363 \\ ${ }^{2}$ Departemen Teknik Elektro Fakultas MIPA Universitas Padjadjaran, \\ Jl. Raya Bandung-Sumedang Km 21, Jatinangor 45363 \\ *email : setianto@phys.unpad.ac.id
}

\begin{abstract}
Abstrak. Lampu lalulintas memegang peranan penting dalam pengaturan kelancaran lalulintas. Sistem pengendalian lampu lalulintas yang baik akan secara otomatis menyesuaikan diri dengan kepadatan arus lalulintas pada jalur yang diatur. Dengan penerapan logika fuzzy, hal ini sangat memungkinkan untuk dilakukan. Permasalahan utama dalam perancangan dan pembuatan modul sistem peralatan pengaturan lampu lalulintas berbasis fuzzy logic ini, adalah perangkat keras tambahan yang terdiri dari : sensor, OpAmp, ADC 0809, Interfacing PPI 8255, Driver, Relay dan Lampu lalulintas (LL). Sedangkan sebagai dasar pengendalian dari sistem yang dijalankan, digunakan algoritma logika fuzzy. Hasilnya, dengan pengendali berbasis fuzzy waktu tunggu ratarata lebih pendek sebesar 5\% dibandingkan menggunakan pengendali konvensional. Kinerja sistem juga mencapai $72 \%$ lebih tinggi.
\end{abstract}

Kata kunci : Lalulintas, Pengaturan, Fuzzy Logic

Abstract. Traffic lights play an important role in the fluent of traffic. A good traffic light control system will automatically adjust to the traffic current density on the regulated path. With the application of fuzzy logic, it is very possible to do the optimum control process. The main problem in designing and manufacturing module of fuzzy logic-based traffic management system equipment is additional hardware consisting of sensor, OpAmp, ADC 0809, PPI 8255 Interfacing, Driver, Relay and Traffic LL (LL). While as the basic control of the systems, we used fuzzy logic algorithm. As result, with fuzzybased controllers waiting time on average shorter by $5 \%$ than using conventional controllers. System performance also reached $72 \%$ higher.

Keywords : Traffic, Controller, Fuzzy Logic

\section{Pendahuluan}

Suatu sistem peralatan yang ditangani oleh komputer, maka semuanya akan terasa lebih canggih, lebih pintar, lebih otomatis, lebih praktis, lebih efisien, lebih aman, lebih teliti dan sebagainya yang menunjukkan keuntungan-keuntungan bila dibandingkan dengan pengerjaan secara manual. Kemampuan komputer dapat diberdayakan melalui peningkatan kemampuan unjuk kerja perangkat keras (hardware) atau pada perangkat lunak (software) atau perpaduan keduanya. Lampu lalulintas memegang peranan penting dalam pengaturan kelancaran lalulintas. Sistem pengendalian lampu lalulintas yang baik akan secara otomatis menyesuaikan diri dengan kepadatan arus lalulintas pada jalur yang diatur. Dengan penerapan logika fuzzy hal ini sangat memungkinkan untuk dilakukan[1]. 
Permasalahan utama dalam perancangan dan pembuatan modul sistem peralatan pengaturan lampu lalulintas berbasis Fuzzy Logic ini, adalah perangkat keras tambahan yang terdiri dari : sensor, OpAmp, ADC 0809, Interfacing PPI 8255, Driver, Relay dan Lampu lalulintas (LL). Sedangkan sebagai dasar pengendalian dari sistem yang dijalankan, digunakan algoritma logika fuzzy[2]. Beberapa istilah yang digunakan dalam pengendalian lampu Lalulintas (LL), antara lain, untuk sebaran kendaraan adalah : Tidak Padat (TP), Kurang Padat (KP), Cukup Padat (CP), Padat (P) dan Sangat Padat (SP). Sedangkan untuk lama nyala lampu LL adalah : Cepat (C), Agak Cepat (AC), Sedang (S), Agak Lama (AL) dan Lama (L). Jelas istilah-istilah tersebut dapat menimbulkan kemenduaan (ambiguity) dalam pengertiannya[2]. Logika Fuzzy dapat mengubah kemenduaan tersebut ke dalam model matematis sehingga dapat diproses lebih lanjut untuk dapat diterapkan dalam sistem kendali. Menggunakan teori himpunan Fuzzy, logika bahasa dapat diwakili oleh sebuah daerah yang mempunyai jangkauan tertentu yang menunjukkan derjat keanggotaannya.

Untuk kasus disini, sebut saja derajat keanggotaan itu adalah $\mathrm{u}(\mathrm{x})$ untuk $\mathrm{x}$ adalah jumlah kendaraan. Derajad keanggotaan tersebut mempunyai nilai yang bergradasi sehingga mengurangi lonjakan pada sistem $[3,4,5]$. Sistem pengendalian fuzzy yang dirancang mempunyai dua masukan dan satu keluaran. Masukan adalah jumlah kendaraan pada suatu jalur yang sedang diatur dan jumlah kendaraan pada jalur lain, dan keluaran berupa lama nyala lampu hijau pada jalur yang diatur. Penggunaan dua masukan dimaksudkan supaya sistem tidak hanya memperhatikan sebaran kendaraan pada jalur yang sedang diatur saja, tetapi juga memperhitungkan kondisi jalur yang sedang menunggu. Pencuplikan dilakukan pada setiap putaran (lewat 8 sensor yang dipasang pada semua jalur). Satu putaran dianggap selesai apabila semua jalur telah mendapat pelayanan lampu.Masukan berupa himpunan kepadatan kendaraan oleh logika fuzzy diubah menjadi fungsi keanggotaan masukan dan fungsi keanggotaan keluaran (lama lampu hijau). Bentuk fungsi keanggotaan dapat diatur sesuai dengan distribusi data kendaraan[6]. Menerapkan logika fuzzy dalam sistem pengendalian, membutuhkan tiga langkah, yaitu Fusifikasi (Fuzzyfication), Evaluasi kaidah dan Defusifikasi (Defuzzyfication). Fusifikasi adalah proses mengubah masukan eksak berupa jumlah kendaraan menjadi masukan fuzzy berupa derajat keanggotaan $\mathrm{u}(\mathrm{x})$. Setelah fusifikasi adalah evaluasi kaidah. Kaidah-kaidah yang akan digunakan untuk mengatur LL ditulis secara subyektif dalam fuzzy associate memory (FAM), yang memuat hubungan antara kedua masukan yang menghasilkan keluaran tertentu[6]. Kaidah-kaidah ini terlebih dahulu dikonsultasikan kepada mereka yang berpengalaman dalam bidang yang akan dikendalikan, yaitu misalnya Polisi Lalulintas dan DLLAJR. Di sini dipakai kaidah hubungan sebab akibat dengan dua masukan yang digabung menggunakan operator DAN, yaitu : Jika (masukan 1) DAN (masukan 2), maka (keluaran), dan ditabelkan dalam Tabel FAM. Sebagai contoh, jika $\operatorname{TP}(0,25)$ dan $\operatorname{KP}(0,75)$, maka $\mathrm{AC}(0,25)$. Di sini keluaran fuzzy adalah Agak Cepat yaitu AC $(0,25)$.

Setelah diperoleh keluaran fuzzy, proses diteruskan pada defusifikasi. Proses ini bertujuan untuk mengubah keluaran fuzzy menjadi keluaran eksak (lama nyala lampu hijau). Karena keluaran fuzzy biasanya tidak satu untuk selang waktu tertentu, maka untuk dihasilkan keluaran eksaknya dipilih keluaran dengan harga yang terbesar. Bila terdapat dua buah derajat keanggotaan berbeda pada akibat yang sama, diambil harga yang terbesar. Sistem pengatur LL yang dirancang ini, juga mempertimbangkan masukan interupsi sebagai prioritas utama, sehingga 
pengaturan LL yang sedang berjalan akan dihentikan sementara untuk melayani jalur yang menyela. Fasilitas ini digunakan untuk keadaan darurat atau mendesak, misalnya seperti pelayanan mobil pemadam kebakaran atau mobil ambulance. Pendeteksian interupsi dilakukan secara terus menerus (residen). Jika lebih dari satu jalur memberi interupsi, maka yang dilayani dulu adalah yang pertama menekan tombol interupsi itu[7].

Tabel 1. FAM Fuzzy Associate Memory untuk kepadatan Lalulintas

\begin{tabular}{cccccc} 
& KP & CP & $\mathbf{P}$ & SP \\
Masukan-2 & TP & C & & & \\
\hline TP & C & AC & S & AL & L \\
P & C & AC & S & AL & L \\
SP & C & AC & S & S & AL \\
\hline
\end{tabular}

Keterangan : Masukan-1 adalah jumlah kendaraan pada jalur yang diatur. Masukan2 adalah jumlah kendaraan pada jalur lain

\section{Metode Penelitian}

Perangkat keras (hardware) yang akan dibuat dirancang sesuai blok diagram berikut:

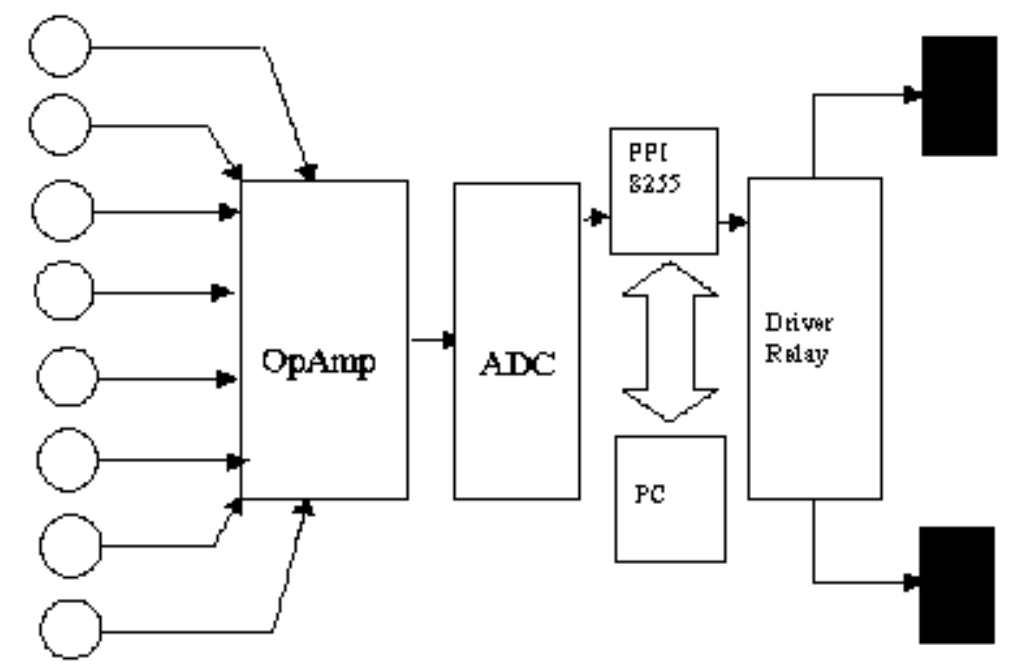

Gambar 1. Diagram blok Perancangan sistem Pengaturan Lampu lalulintas berbasis Fuzzy Logic 
Perangkat lunak (software) yang dibuat dibagi menjadi beberapa bagian besar antara lain meliputi algoritma pengambilan dan masukan, pengiriman data keluaran, pengolahan data secara fuzzy, dan proses kendalinya. Perangkat lunak ini direalisasikan menggunakan Turbo Pascal. Algoritma program utama mengikuti proses sebagai berikut : mula-mula PPI diinialisasi dengan mengirimkan control word ke register kendali PPI. Dengan mengirimkan nilai 90h ke register kendali PPI, maka port A akan berfungsi sebagai masukan dan port B serta port C akan berfungsi sebagai keluaran. Selanjutnya akan dikirimkan pulsa reset ke semua input ADC, pada saat awal seluruh jalur akan diberi lampu merah. Setelah proses ini, program melakukan proses yang berulang-ulang, yaitu proses pengambilan data pada tiap sensor, pengolahan data dan proses pengaturan fuzzy menggunakan prinsip-prinsip yang telah dibahas di atas dan menjalankan pengaturan sesuai dengan tabel kendali yang telah dibuat.

\section{Hasil dan Pembahasan}

Pengendali berbasis logika fuzzy telah diuji di bawah lima jenis kondisi lalu lintas yang berbeda dari lalu lintas yang sangat padat hingga lalu lintas yang sangat jarang. Kepadatan mobil yang dipilih secara acak dan dikelompokkan menurut periode berbeda hari yang mewakili kondisi lalu lintas tersebut. Evaluasi kinerja dan performa pengendali logika fuzzy dibandingkan dengan pengendali konvensional. Kriteria yang digunakan untuk perbandingan adalah jumlah mobil yang diperbolehkan lewat pada satu waktu dan waktu tunggu rata-rata. Indeks kinerja dipakai untuk memaksimalkan arus lalu lintas dan mengurangi waktu tunggu ratarata. Namun, perhitungan rinci dari evaluasi ini tidak dibahas dalam artikel ini. Kedua jenis pengendali lalu lintas tersebut dibandingkan dan dapat dirangkum dengan grafik indek kinerja berikut di lima kategori lalu lintas.

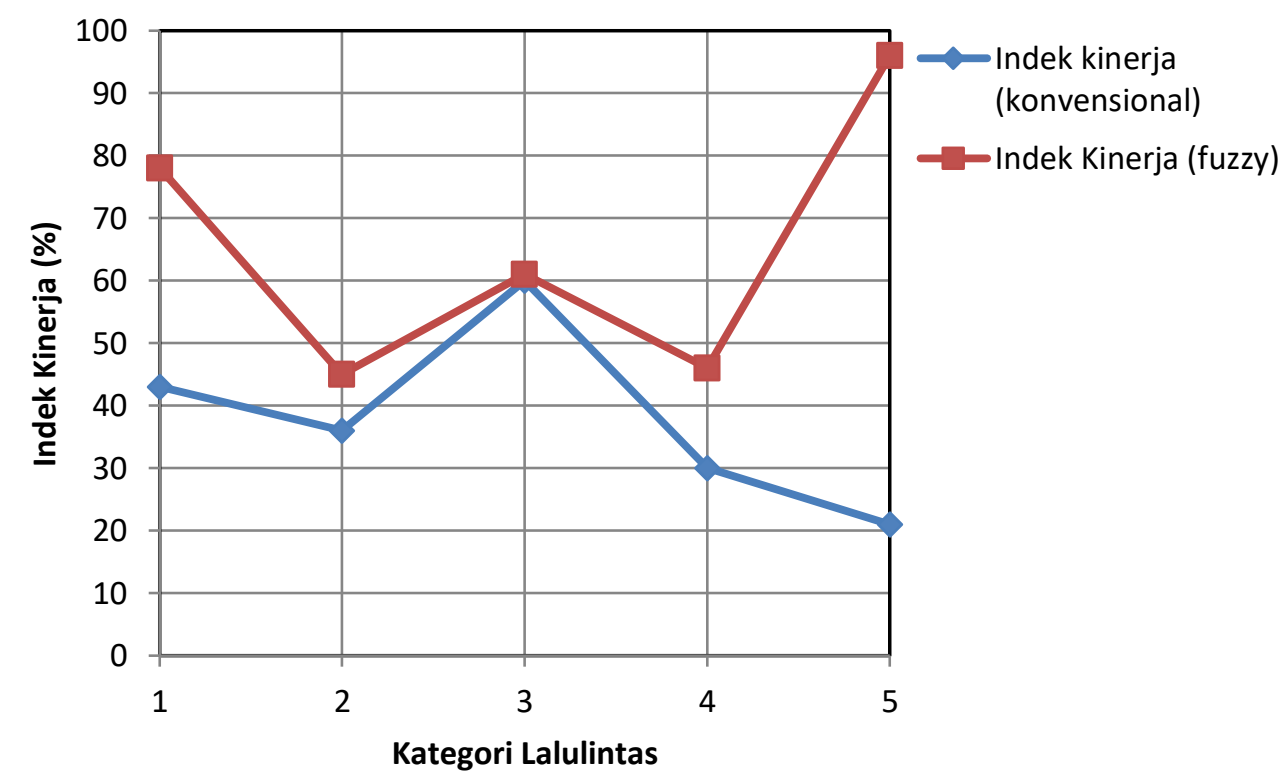

Gambar 2. Grafik Indek Kinerja sistem terhadap kategori lalulintas 
Pengendali berbasis fuzzy waktu tunggu rata-rata lebih pendek sebesar 5\% dibandingkan menggunakan pengendali konvensional. Kinerja sistem juga mencapai $72 \%$ lebih tinggi.

\section{Kesimpulan}

Dari hasil perancangan dan uji coba sistem yang dibuat, logika fuzzy terbukti dapat digunakan untuk memenuhi tujuan pengaturan lalulintas secara optimal. Sistem yang dihasilkan relatif sederhana dan mempunyai fleksibilitas tinggi. Sistem ini dapat diterapkan di kondisi jalan yang berbeda, yaitu lewat penyesuaian ranah (domain) himpunan fungsi keanggotaan masukan dan keluaran dan kaidah-kaidah kendali pada Fuzzy Associative Memory (Tabel FAM).

\section{Daftar Pustaka}

1. J. W. Lea, Sistem Pengaturan Lampu Lalulintas dengan Menggunakan Teori Himpunan Fuzzy, September 1994.

2. S. Marsh et al., Fuzzy Logic Education Program, Center of Emerging Computer Technologies, Motorola Inc., 1992.

3. P. G. Balaji and D. Srinivasan, Type-2 fuzzy logic based urban traffic management, Engineering Applications of Artificial Intelligence, Vol. 24 No. 1 (2011) p. 12-22.

4. H. Singh, M. M. Gupta, T. Meitzler et al., Real-life applications of fuzzy logic, Advances in Fuzzy Systems, Vol. 2013, Article ID 581879 (2013) 3 pages.

5. S. Mehan, Introduction of traffic light controller with fuzzy control system, International Journal of Electronics \& Communication Technology, Vol. 2 No. 3 (2011) p. 119-122.

6. R. Hou, Q. Wang, J. Wang, J. Wang, Y. Lu, and J. Kim, A fuzzy control method of traffic light with countdown ability, International Journal of Control and Automation, Vol. 5 No. 4 (2012) p. 93-102.

7. H. Pranevicius and T. Kraujalis, Knowledge based traffic signal control model for signalized intersection, Transport, Vol. 27 No. 3 (2012) p. 263-267. 